\title{
Work profile of maritime pilots in Germany
}

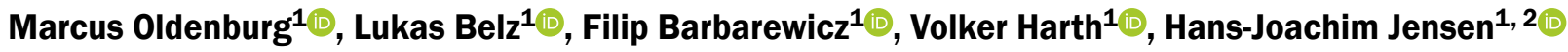

${ }^{1}$ Institute for Occupational and Maritime Medicine Hamburg (ZfAM), University Medical Centre Hamburg-Eppendorf (UKE), Germany

${ }^{2}$ Flensburg University of Applied Sciences, Germany

\begin{abstract}
Long and irregular shifts, unforeseeable operations and high responsibility are still prominent in the job of a pilot and pose high psycho-physical demands. Furthermore, there is a disturbed work-family balance. Working hours of pilots are highly variable and not bound by regulations due to irregularities of vessel traffic. The pilots have to work in a shifting rotation system. This paper demonstrates the stressors during their work routine and shows the usual working profile of a pilot during their service.
\end{abstract}

(Int Marit Health 2020; 71, 4: 275-277)

\section{Key words: pilot, work profile, stressors}

\section{REVIEW}

In the frame of globalisation and increasing trading relations, international trade takes a key position in world economy. Almost $90 \%$ of modern global trade is depending on sea transport. For this sector, seafarers, who are exposed to harsh conditions during ship operations, are essential [1-3]. Pilotage furthermore has a special role in the maritime industry [4].

During his service on the bridge, the pilot is officially only a consultant for the ship's head of the watch. He knows local currents in relation to tides and current sea and weather conditions as well as depths and widths of the waterway. This knowledge is the foundation for important decisions for piloting to the port of destination. To know these regional factors, which can change spontaneously, for several ports is impossible for the ship's master. The pilot's expertise about his pilotage waters is necessary and cannot be replaced by modern vessel traffic services and surveillance systems, radar, GPS or electronic chart systems.

\section{CURRENT RELEVANCE OF PILOTS IN GERMANY}

In the course of rising and internationally expanding trade, the size of vessels and their tonnage have increased continuously until today. Since the late nineties the maximum twenty-foot equivalent unit (TEU) capacity of container ships has more than tripled resulting in bigger ships which are harder to operate in narrow channels (Table 1) [5].
With annual more than 100,000 vessel movements, the German Bight features one of the highest ship densities of the world. This amount of traffic, with the ongoing trend to larger vessels, enhances the risk of collisions and accidents with catastrophic impacts. Since 2015 there have been at least 112 maritime accidents in German waters each year [6].

In order to ensure traffic safety, there is an obligation to use pilot services for in and outgoing vessels. In Germany, the law of sea pilots (Seelotsgesetz) requests a permanent availability of pilots on 365 days at all times. This is surveyed strictly by regional supervisory authorities. For the river Elbe and the port of Hamburg there is a pilot acceptance obligation for all vessels, which are longer than $90 \mathrm{~m}$ overall and wider than $13 \mathrm{~m}$ and all tanker vessels. For a passage through the Kiel Canal any bigger ship passing the channel is obligated to take a channel pilot and a channel helmsman in order to avoid collisions.

Today, pilots in Germany are freelancers and execute the delegated pilotage services according to the law of sea pilots section 21 paragraph 1 SeeLG (1954) in self-administration. Pilots are therefore working in a self-employed and non-commercial environment, which is neither controlled by worker-protection laws nor the commercial inspectorate.

The usually unpredictable arrival of the ship, the transfer on board the ship and advising the captain during the passage through the specific waterway are general and typical features of the pilots' job. Thus, according to the International Maritime Pilots Association (IMPA), the working 
Table 1. Development of ship sizes of container vessels between the late 1990s and 2020. The biggest representatives after: Research-Information-System for Mobility and Traffic [13]

\begin{tabular}{llllll}
\hline Year & Ship & Capacity & Length & Width & Draft \\
\hline End of 1990s & S-Klasse Maersk-Sealand & 6,600 TEU & $347 \mathrm{~m}$ & $42.8 \mathrm{~m}$ & $14.6 \mathrm{~m}$ \\
2004 & CSCL Asia & $8,500 \mathrm{TEU}$ & $334 \mathrm{~m}$ & $42.8 \mathrm{~m}$ & $14.5 \mathrm{~m}$ \\
2006 & Emma Maersk & $14,000 \mathrm{TEU}$ & $397 \mathrm{~m}$ & $56 \mathrm{~m}$ & $15.5 \mathrm{~m}$ \\
2013 & Maersk Mc-Kinney Møller & 18,000 TEU & $400 \mathrm{~m}$ & $59 \mathrm{~m}$ & $14.5 \mathrm{~m}$ \\
2015 & MSC Oscar & 19,224 TEU & $395.4 \mathrm{~m}$ & $59 \mathrm{~m}$ & $16 \mathrm{~m}$ \\
2017 & OOCL Hong Kong & 21,413 TEU & $399.9 \mathrm{~m}$ & $58.8 \mathrm{~m}$ & $16 \mathrm{~m}$ \\
2020 & HMM Algeciras & 22,000 TEU & $399.9 \mathrm{~m}$ & $61 \mathrm{~m}$ & $16.5 \mathrm{~m}$
\end{tabular}

situation of a pilot in global maritime shipping is comparable, regardless of the country in which they operate $[7,8]$.

\section{TYPICAL STRAINS AND STRESSES OF PILOTS}

Long and irregular shifts, unforeseeable operations and high responsibility are still prominent in the job of a pilot and pose high psycho-physical demands. Furthermore, there is a disturbed work-family balance. Working hours of pilots are highly variable and not bound by regulations due to irregularities of vessel traffic. A high number of operations take place during night time conflicting with the pilots' biorhythm.

In order to maintain a permanent availability of pilots, a rotation system has been established, which is comparable to the queue at a taxi stand. The pilot who is on the first position of the queue is assigned to the next vessel requiring pilotage. If his pilotage service is finished he moves to the end of the queue and the next operation starts when he is again first in the queue. Today, most pilot associations in Germany struggle with finding staff, which shortens the queue [9]. This makes daily operations less predictable and can disturb work-life balance.

The usual working profile of a pilot during pilot-service consists of the following steps.

1. Initially, the pilot is on standby at a pilot station on a pilot boat or even at home. Depending on the working-system the pilot is called long before the actual start of operation. Often, it is rather uncertain how long the stand by time can last.

2. When called the pilot usually transfers to the vessel by pilot boat, taxi or on foot. If the ship is not moored when the pilotage begins, the actual pilot transfer contains going alongside the vessel, boarding via the pilot ladder and climbing several stairs on board to reach the bridge. The physical stress can be high in this phase, depending on size and height of the vessel. This procedure contains the highest risk for accidents during pilot operation es- pecially because it has to be done in any weather and sea conditions while the vessel is making way.

3. The actual piloting takes place on the bridge in presence of the master of the vessel. The master knows its vessel, the pilot the local conditions. A safe navigation requires the cooperation of both. While a pilot is on board a master occasionally is not present on the bridge. He often transfers the navigation on one of his mates and the pilot. This period is an additional psychological challenge. Despite his only consulting status the pilot undertakes tasks of the master and is actually leading the bridge team. This is a rather unique situation taken into account, that the pilot does not know the crew he is working with or their competence. He cannot even be sure if communication will be easy, because the ability to speak English highly varies on international ships.

However, in case of an accident a pilot is not liable except in cases of gross negligence. The responsibility of the safe handling of the vessel always remains with the ship's command.

4. After the operation, the pilot returns to the pilot station, changes to a recreational phase and waits for the next assignment. This phase is the most challenging for many pilots, because usually it is unknown which vessel is next and when it will arrive. Due to this uncertainty there is often an "anticipatory anxiety" which leads to high psychological strain.

Based on our own recent yet unpublished evaluations, incoherency between job requirements and family/leisure is one of the biggest psycho-social problems of pilots. The unique status of pilots as freelancers organised in pilots associations makes it hard to compare their working conditions to those of other occupational groups [10].

An overview on scientific publications on this topic is given by Chambers and Main [4]. The authors observed that pilots compared to the general population ashore are at higher risk to develop diseases. Cardio-vascular and psychological diseases as well as accidents were frequently 
found in 18 analysed studies. Specifically, on-call work periods that occur at irregular times with irregular pilotage are a major cause of poor sleep quality and quantity. These potential risks factors for fatigue can lead in the long-term to cognitive dysfunction and emotional disorders [11]. According to Strauch [12], fatigue also poses a risk factor for accidents, although further studies are still needed to evaluate these relationships in more detail.

Furthermore, an unhealthy lifestyle is discussed as major risk factor among pilots. A former study revealed that this occupational group compared to the general population is more likely to exhibit overweight, smoking, high lipid serum levels, lack of physical activity and unhealthy eating habits [13].

Closer analyses of this occupation show its impact on individual psycho-physical health and on concentration and performance levels of pilots. These influences are visible in sleeping disorders [14], cognitive disorders, limitation of vigilance [4] and more accidents [15]. In general, the health and wellbeing of pilots has been yet analysed insufficiently [16] and further research is necessary.

\section{FUNDING}

This study was funded by the German Maritime Pilots' Association, Hamburg, Germany.

\section{CONFLICT OF INTEREST}

There are no conflicts of interest.

\section{REFERENCES}

1. Carotenuto A, Molino I, Fasanaro AM, et al. Psychological stress in seafarers: a review. Int Marit Health. 2012; 63(4): 188-194, indexed in Pubmed: 24595974.

2. Nielsen MB, Bergheim K, Eid J. Relationships between work environment factors and workers' well-being in the maritime industry. Int Marit Health. 2013; 64(2): 80-88, indexed in Pubmed: 23788224.

3. Oldenburg $\mathrm{M}$, Jensen $\mathrm{HJ}$, Latza $\mathrm{U}$, et al. The risk of coronary heart disease of seafarers on vessels sailing under a German flag. Int Marit Health. 2010; 62(3): 123-128, indexed in Pubmed: 21154298.
4. Chambers TP, Main LC. Symptoms of fatigue and coping strategies in maritime pilotage. Int Marit Health. 2015; 66(1): 43-48, doi: 10.5603/IMH.2015.0011, indexed in Pubmed: 25792167.

5. The Impact of Mega-Ships. International Transport Forum Policy Papers. Organisation for Economic Co-operation and Development, Paris. 2015, doi: 10.1787/5jlwvzcm3j9v-en.

6. Federal Bureau of Maritime Casualty Investigation. Jahresbericht 2019. 2020.

7. Marine Insight News Network. Maritime pilot and his duties. 2019. https://www.marineinsight.com/careers-2/maritime-pilot-and-his-duties/ (30.10.2020).

8. Andresen M, Domsch M, Cascorbi A. Working Unusual Hours and Its Relationship to Job Satisfaction: A Study of European Maritime Pilots. J Labor Res. 2007; 28(4): 714-734, doi: 10.1007/s12122007-9010-5.

9. Runge W. Elblotsen haben Nachwuchssorgen 2019. https://www. welt.de/print/die_welt/hamburg/article198817903/Elblotsen-haben-Nachwuchssorgen.html (24.08.2020).

10. Saarni H, Niemi L, Pentti J, et al. Is there need for change of health examinations for sea pilots? Bulletin of the Institute of Maritime and Tropical Medicine in Gdynia. 1992; 43(1-4): 25-34, indexed in Pubmed: 1345594.

11. Gregory K, Hobbs A, Parke B, et al. An evaluation of fatigue factors in maritime pilot work scheduling. Chronobiol Int. 2020 [Epub ahead of print]: 1-7, doi: 10.1080/07420528.2020.1817932, indexed in Pubmed: 32911999.

12. Strauch B. Investigating Fatigue in Marine Accident Investigations. Procedia Manufacturing. 2015; 3: 3115-3122, doi: 10.1016/j. promfg.2015.07.859.

13. Barbarewicz F, Jensen HJ, Harth V, et al. Psychophysical stress and strain of maritime pilots in Germany. A cross-sectional study. PLoS One. 2019; 14(8): e0221269, doi: 10.1371/journal.pone.0221269, indexed in Pubmed: 31415636.

14. Ferguson SA, Lamond N, Kandelaars K, et al. The impact of short, irregular sleep opportunities at sea on the alertness of marine pilots working extended hours. Chronobiol Int. 2008; 25(2): 399-411, doi: 10.1080/07420520802106819, indexed in Pubmed: 18484370.

15. Meere K, Van Da, Van Sp. Occupational injuries in Flemish pilots in Belgium. A questionnaire survey. Int Marit Health. 2005; 56(1-4): 67-77, indexed in Pubmed: 16532586.

16. Main LC, Chambers TP. Factors affecting maritime pilots' health and well-being: a systematic review. Int Marit Health. 2015; 66(4): $220-$ 232, doi: 10.5603/IMH.2015.0043, indexed in Pubmed: 26726893. 